\title{
ENTERPRISE BUSINESS PROCESS MANAGEMENT AND MODELLING
}

\author{
Gvidas Petružis, PhD student, Vilnius University Šiauliai Academy, Lithuania \\ Teodoras Tamošiūnas, Prof., Vilnius University Šiauliai Academy, Lithuania \\ teodoras.tamosiunas@gmail.com
}

\begin{abstract}
The article examines the variety of business process management concepts that are especially broad in small and medium-sized enterprises. The features of business process management under the conditions of cooperation of enterprises have been distinguished. Based on the results of the empirical research, the stages of business process modelling of small manufacturing enterprises operating in cooperation with a medium or large enterprise of the same economic activity have been described. The importance of information technology, expert competencies and experience in modelling business processes has been emphasized.
\end{abstract}

Key words: business processes, cooperation, management, modelling

\section{INTRODUCTION}

The term 'business model' is often discussed in research papers. The business model is understood as a modern means of increasing the competitiveness of business enterprises in the market. However, despite the extensive scientific debate, there is no single business model concept [1]. Every business enterprise operates according to a specific business model, the essence of which is to help earn maximum profit with minimal costs [2].

Often, a business model is defined as the management of a company's internal processes and its transactions with partners. The business model designs and schematically describes the activities of business enterprises in order to highlight long-term and stable processes. In addition, business process models often seek to incorporate elements of innovation that increase business efficiency [3].

Following the concept of division of labour developed by Adam Smith in the 18th century, many business modelling theorists sought to break down work into individual tasks performed by employees with the appropriate skills to perform the functions assigned to them. A traditional business organization is based on vertical management, in which departments or individuals are responsible for specific areas, such as finance, research, 
manufacturing operations, logistics, etc. Business processes combine these business groups, transcend functional boundaries, and combine input (order, raw materials) with output (completed service, final output). However, the functional structure of organizations is usually inflexible and slow to respond to change.

Business process management involves the improvement and optimization of business processes in order to increase the value and productivity of the enterprise. Using business processes to increase enterprise efficiency becomes " $a$ boundaryless approach to modern competitiveness" [4]. In order to increase the efficiency of the enterprise's operations, it is necessary to know what business processes take place in the enterprise and how they are interconnected. A development-oriented enterprise models and documents its business processes as well as improves and controls them.

The article aims to summarize the theoretical concepts of business process modelling and, based on the results of empirical research, to describe the stages of business process modelling in small manufacturing companies.

\section{BUSINESS PROCESS IDENTIFICATION}

In order to identify business processes in an organization, their operating structure has to be clearly defined. Processes need to be assessed holistically, taking into consideration organizational possibilities, according to the life cycle of the process modelling tasks: to identify, model, analyse, improve, implement, execute, monitor, and modify. This requires knowing all the potential perspectives of the organization and identifying the key areas of opportunity that are important for successful business process management.

Table 1 presents the six key elements of business process management: 1) strategic management; 2) governance; 3) methods; 4) information technology; 5) people; 6) culture $[5]$.

Table 1. Six key elements of business process management

\begin{tabular}{|l|l|l|l|l|l|}
\hline $\begin{array}{l}\text { Strategic } \\
\text { manageme } \\
\text { nt }\end{array}$ & Governance & Methods & $\begin{array}{l}\text { Information } \\
\text { technology }\end{array}$ & People & Culture \\
\hline $\begin{array}{l}\text { Process } \\
\text { Improveme } \\
\text { nt Planning }\end{array}$ & $\begin{array}{l}\text { Process } \\
\text { Management }\end{array}$ & $\begin{array}{l}\text { Process } \\
\text { Design and } \\
\text { Decision }\end{array}$ & $\begin{array}{l}\text { Process } \\
\text { Modelling }\end{array}$ & $\begin{array}{l}\text { Process } \\
\text { Skills and } \\
\text { Expertise }\end{array}$ & $\begin{array}{l}\text { Responsiven } \\
\text { ess to } \\
\text { Process }\end{array}$ \\
\hline
\end{tabular}




\begin{tabular}{|c|c|c|c|c|c|}
\hline & Making & & & & Change \\
\hline $\begin{array}{l}\text { Strategy } \\
\text { and Process } \\
\text { Capability } \\
\text { Linkage }\end{array}$ & $\begin{array}{l}\text { Process } \\
\text { Roles and } \\
\text { Responsibilit } \\
\text { ies }\end{array}$ & $\begin{array}{l}\text { Process } \\
\text { Implementati } \\
\text { on and } \\
\text { Execution }\end{array}$ & $\begin{array}{l}\text { Statistical } \\
\text { Data Analysis }\end{array}$ & $\begin{array}{l}\text { Process } \\
\text { Managemen } \\
\mathrm{t} \\
\text { Knowledge }\end{array}$ & $\begin{array}{l}\text { Process } \\
\text { Values and } \\
\text { Beliefs }\end{array}$ \\
\hline $\begin{array}{l}\text { Enterprise } \\
\text { Process } \\
\text { Architectur } \\
\mathrm{e}\end{array}$ & $\begin{array}{l}\text { Process } \\
\text { Metrics and } \\
\text { Performance } \\
\text { Linkage }\end{array}$ & $\begin{array}{l}\text { Process } \\
\text { Monitoring } \\
\text { and Control }\end{array}$ & $\begin{array}{l}\text { IT-Based } \\
\text { Solutions }\end{array}$ & $\begin{array}{l}\text { Process } \\
\text { Education }\end{array}$ & $\begin{array}{l}\text { Process } \\
\text { Attitudes and } \\
\text { Behaviours }\end{array}$ \\
\hline $\begin{array}{l}\text { Process } \\
\text { Measures }\end{array}$ & $\begin{array}{l}\text { Process } \\
\text { Related } \\
\text { Standards }\end{array}$ & $\begin{array}{l}\text { Process } \\
\text { Improvement } \\
\text { and } \\
\text { Innovation }\end{array}$ & $\begin{array}{l}\text { Managing } \\
\text { Information } \\
\text { Systems }\end{array}$ & $\begin{array}{l}\text { Process } \\
\text { Collaboratio } \\
\mathrm{n}\end{array}$ & $\begin{array}{l}\text { Leadership } \\
\text { Attention to } \\
\text { Process }\end{array}$ \\
\hline $\begin{array}{l}\text { Process } \\
\text { Customers } \\
\text { and } \\
\text { Stakeholder } \\
\text { s }\end{array}$ & $\begin{array}{l}\text { Process } \\
\text { Management } \\
\text { Compliance }\end{array}$ & $\begin{array}{l}\text { Process } \\
\text { Program and } \\
\text { Project } \\
\text { Management }\end{array}$ & $\begin{array}{l}\text { Simulation of } \\
\text { Real } \\
\text { Processes }\end{array}$ & $\begin{array}{l}\text { Process } \\
\text { Managemen } \\
\text { t Leaders }\end{array}$ & $\begin{array}{l}\text { Process } \\
\text { Management } \\
\text { Social } \\
\text { Networks }\end{array}$ \\
\hline
\end{tabular}

Source: [5]

1. Strategic management: Business process management has to be aligned with the overall strategy of the organization. Strategic management (or synchronization) is defined as a close link between an organization's priorities and processes that enable effective action to improve business performance. Processes need to be created, implemented, managed and measured in terms of strategic priorities and specific strategic situations. In turn, process-specific possibilities enable to improve strategy.

2. Governance: Business process management creates appropriate and transparent responsibilities at all levels of process management, both in decision-making and in compliance with process-related standards. Much attention is paid to the planning of decision-making and remuneration processes.

3. Methods: Within the context of business process management, methods are defined as a set of tools and techniques that support and enable activities throughout the process lifecycle. These methods facilitate process modelling or process analysis and enable process improvement. 
4. Information technology: IT-based solutions are important for business process management. As the traditional focus is on statistical process analysis and process modelling support, IT solutions related to business process management are increasingly emerging as the process information management systems. The software clearly and specifically reflects the ongoing processes. Such simulation of real processes can take the form of process models in IT systems or can be integrated into specialized applications.

5. People: Human resources as a key element of business process management are defined as individuals and groups who improve their activities and apply process management skills and knowledge to improve business performance. The development of business participants increases the possibilities of business process management.

6. Culture: Organizational culture covers the collective values of people; it has a strong impact on the success of business processes. Culture is aimed to create a supportive environment for business process management and vice versa - business process management promotes an organizational culture that supports it. The element of business process management culture is closely related to the other five elements of business process management [5].

Hammer [6] emphasizes two essential components in business process management: 1) Business Process Reengineering and 2) Statistical Process Control. He described business process management as an "integrated business performance management system". Business process management includes the measurement of business processes and the analysis of key business planning data.

Davenport [7] describes business process management as "a structured, measured set of activities designed to produce specific products for a specific customer or market". A business process is a specific distribution of work activity in time and space with a beginning and ending and clearly defined costs and action structure. In business process management, the focus is on how the work is done in the company, not just what is produced. Business process management involves the interaction of customers, employees, and partners. Business processes often have to be adapted quickly and efficiently to changing conditions with minimal time and costs. Business process management is a set of related, structured activities or tasks that create a specific service or product for specific customers.

Singh [8] distinguished three groups of business process management: 1) management of the overall operation of the system. Such a management group includes corporate governance or strategic management; 2) management of processes that regulate key business chains and create value-added flow. Typical processes for such activities are purchasing, manufacturing, 
marketing, and sales; 3) management of the processes supporting the core business, such as accounting, recruitment, training, and technical assistance.

In addition, Singh [8] underlined 10 main typical areas of business process management: 1) customer relationship strategy (marketing); 2) search for employees, employment, qualification improvement and promotion of their satisfaction; 3) improvement of activity quality and change management; 4) financial analysis, accounting and capital management; 5) management structure, distribution of functions and responsibilities; 6) purchase of raw materials and equipment (purchases of goods or services); 7) production of products or development of service; 8) sales of products or provision of service; 9) document management; 10) management of technological processes.

\section{SPECIFICITY OF SMALL AND MEDIUM BUSINESS PROCESS MANAGEMENT}

Many different studies have been conducted and described in the scientific literature to investigate the specifics of small and medium business activities. Managers of small enterprises have been offered a lot of theories and practical advice on how to improve performance and increase business turnover. However, due to the heterogeneity of small enterprises and the different nature of their activities, which depends on the specific environment, it is difficult to find a "best practice" strategy that a small enterprise should pursue in order to grow.

In vague and complex environments, the managers of some small enterprises make decisions that lead to successful growth. The question arises: what do the managers of these successful small enterprises do in their small, fast-growing enterprises, can others learn from them, or does their business success lie in masterful management of internal business processes, or in external factors independent of them?

Many factors affect the performance of a small enterprise. Researchers point out that small enterprises are heavily influenced by laws and regulations, relationships with external factors in their business, enterprise size and age as well as experience gained, local context, ability to adapt to rapidly changing market conditions, innovation, etc. [9].

Small enterprises typically lack skilled workers who can fully perform certain organizational, production functions within the enterprise. Managers of small enterprises are actively involved in day-to-day operations, so the use of effective management tools is especially important for small enterprises. With the often uncertain situation of responsibilities and 
positions in the enterprise, small business managers need to make vital management decisions where more attention is needed and where there is the greatest potential for improving the enterprise's performance. Small business managers often face a dilemma: whether to use scientifically researched and applied business process management mechanisms in their enterprise activities, or how often practice shows, to rely on their intuition and experience as an entrepreneur [10].

Managers of small, fast-growing manufacturing enterprises engage in many different activities. However, several key activities usually take up most of their time: production activities (supply of raw materials, equipment and infrastructure, production, marketing, and sales) and administrative activities (company personnel management, organization of activities, and finance). Tell's study [11] found that managers of small manufacturing enterprises spend 55 percent of the time on production-based issues, 33 percent - on administrative issues and only 12 percent of time devote to strategic activities. This study suggests that the need for strategic planning skills and business process management models adapted to small manufacturing enterprises should be high.

\section{BUSINESS PROCESS MANAGEMENT UNDER COOPERATION CONDITIONS}

In today's economy, cooperation is no longer a free choice but a necessity for enterprises seeking long-term competitiveness in the market. Business based on knowledge and innovation, globalization, and increasing competition is stimulated to move from a traditional business enterprise to organizations connected to a network of cooperating organizations. Organizational networks have many advantages, but they face challenges and problems, mainly related to the complexity of the collaborative environment. The complexity of interorganizational cooperation processes makes it very difficult to model these processes, as it is necessary to have a good understanding of the peculiarities of business process management and to assess the impact of cooperation on these business processes.

Cooperative-driven business processes involve complex interactions between participants and the need to share knowledge in modelling dynamic, unstructured, unique, unpredictable processes. To successfully model a business process conditioned by cooperation, the enterprise needs to have a strong inter-organizational structure, flexible and adaptable working conditions, mutual trust, which allows companies to cooperate, technologies suitable for cooperation, communication that enables the use of a set of basic methods and tools [12]. Figure 1 shows the interaction of business processes of two enterprises when the enterprises 
operate in mutual cooperation. In this case, the closed internal business processes of both enterprises are coordinated with each other through public business processes known to both enterprises. All three business process groups are mostly managed by specialized information technology (IT).

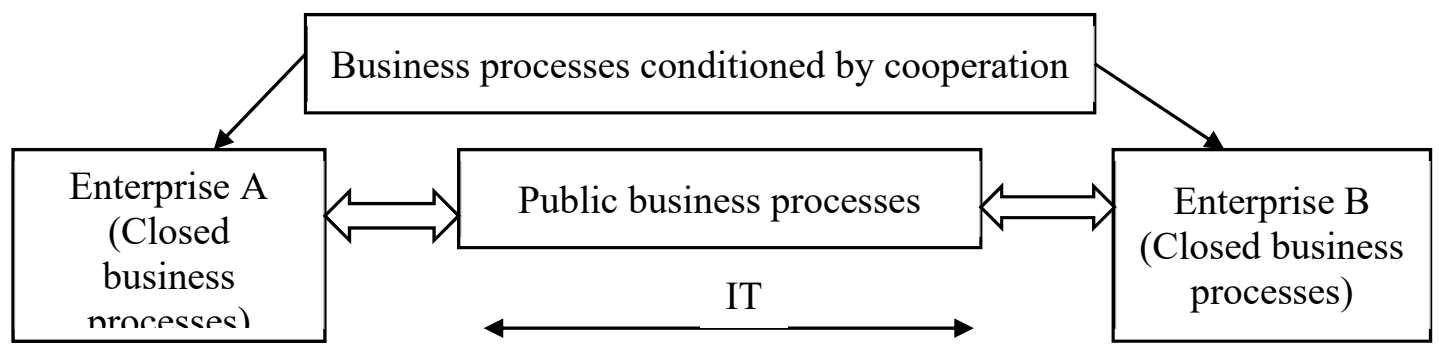

Fig. 1. Interaction of business processes of two enterprises operating in cooperation, Source: [12]

Most often, business process modelling is directed to the inside of the company, i.e. modelling business processes that take place within the enterprise. However, when modelling business processes caused by cooperation, it is important to assess the impact of cooperation of several enterprises on internal business processes, possible differences in business cultures, peculiarities of process synchronization, possible competitions, etc.

It is generally accepted that the business processes affected by cooperation add more value to organizations [12]. In order to assess the impact of cooperation on business processes, it is necessary to have tools and methods that can be used to measure the impact of cooperation on business processes. Cooperative networks rely on the individual knowledge of the participants, resulting in a high degree of complexity in the evaluation of such systems. Interactive structures have been developed for the management of cooperation-driven business processes, supporting consistent and fast, efficiency-based solutions. However, the cooperative relationship has often to be reorganized in such structures in a short period of time and there is not enough time to test and optimize the correspondingly changed business processes. In addition, the decision-making process caused by cooperation becomes complicated due to the large number of variables involved in the modelling [13].

About 50 percent of cooperation factors are people-related, and process and technologyrelated factors account for 30 percent and 20 percent, respectively [14]. According to the significant influence of the human factor, it can be concluded that the success of cooperation can be seen as the satisfaction of the stakeholders involved in the cooperation processes. 


\section{MODELLING OF BUSINESS PROCESSES OF SMALL MANUFACTURING ENTERPRISES}

A number of business process modelling tools have been developed. One of them is Business Process Model Notation (BPMN). It is a new standard for business process modelling, a tool for researchers and business practitioners to model with diagrams and improve complex business processes. With the BPMN standard, business analysts create business process projects based on information received from business participants who implement these business process models in business practice [ [15].

According to the Law on Small and Medium Business Development of the Republic of Lithuania, an enterprise is small if it employs from 10 to 50 employees and the enterprise's annual income does not exceed 10 million euro, or the value of the assets indicated in the enterprise's balance sheet does not exceed 10 million euro. An enterprise is average if it has between 50 and 250 employees and the enterprise's annual income does not exceed 50 million euro, or the value of the assets indicated in the enterprise's balance sheet does not exceed 43 million euro.

In 2020 , the authors of this article investigated three small metal processing production enterprises operating in cooperation with a medium or large enterprise of the same economic activity in Lithuania. The research process shown in Figures 2 and 3 proceeded analogously in all three enterprises in the following five stages:

1. First, an in-depth interview was conducted with the manager of enterprise A1 about the business processes taking place in his enterprise (see Fig. 2). Based on the results of this interview, the enterprise's business processes were drawn according to BPMN v. 2.0 standard Bonita BPM (Business Process Management) program. The obtained business process models were submitted to the manager of enterprise A1 and were revised after receiving his comments.

2. This was followed by in-depth interviews with the managers of the enterprises A2 and A3 about the business processes in their enterprises and the business processes of their enterprises were drawn accordingly. The obtained business process models were presented to the managers of the enterprises A2 and A3 and were revised after receiving their comments.

3. In the third stage of the research, the respective business process models of the three enterprises were compared, using the Jaccard coefficient method [15] (see Fig. 3). If the model was not sufficiently similar to the other two relevant models, a generalized alternative to the business process core (key process areas) model similar to the corresponding models of 
the other two enterprises was developed. When the business process models of all three enterprises met similar criteria, the generalized models of the business process core (key process areas) were developed. Four business process models were obtained: marketing, purchasing, design and manufacturing enterprises operating in cooperation with a medium or large enterprise of the same economic activity.

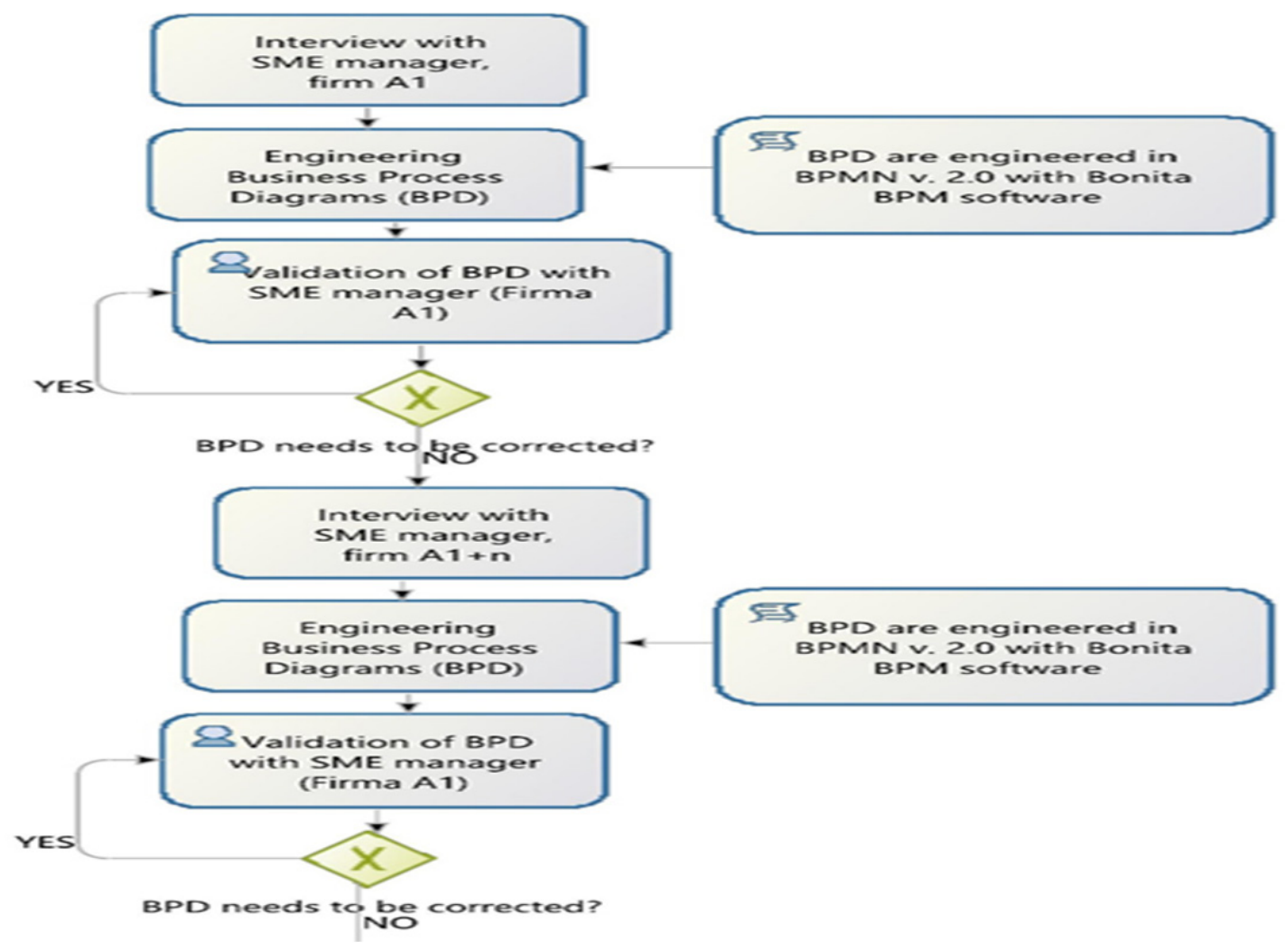

Fig. 2. Stages 1 and 2 of the research: interviews with enterprise managers for business process modelling,

Source: Compiled by the authors

4. The summarized models of the four business processes were submitted for evaluation by 5 experts. Based on their experience and the best practices of other small metalworking manufacturing enterprises, the experts made suggestions for refining the four business process models. According to experts' suggestions, the generalized models of the four business processes were specified.

5. The fifth stage of the research is planned for 2021, the aim of which is to assess the impact of cooperation on business processes. The experts will be presented with the summarized models of the four business processes and the experts will provide their insights on the impact of cooperation on business processes. After analysing the impact of cooperation on business processes, the authors of this research will provide recommendations for the use of 
business process models to small metalworking manufacturing enterprises in the conditions of cooperation with a medium or large enterprise with the same economic activity.

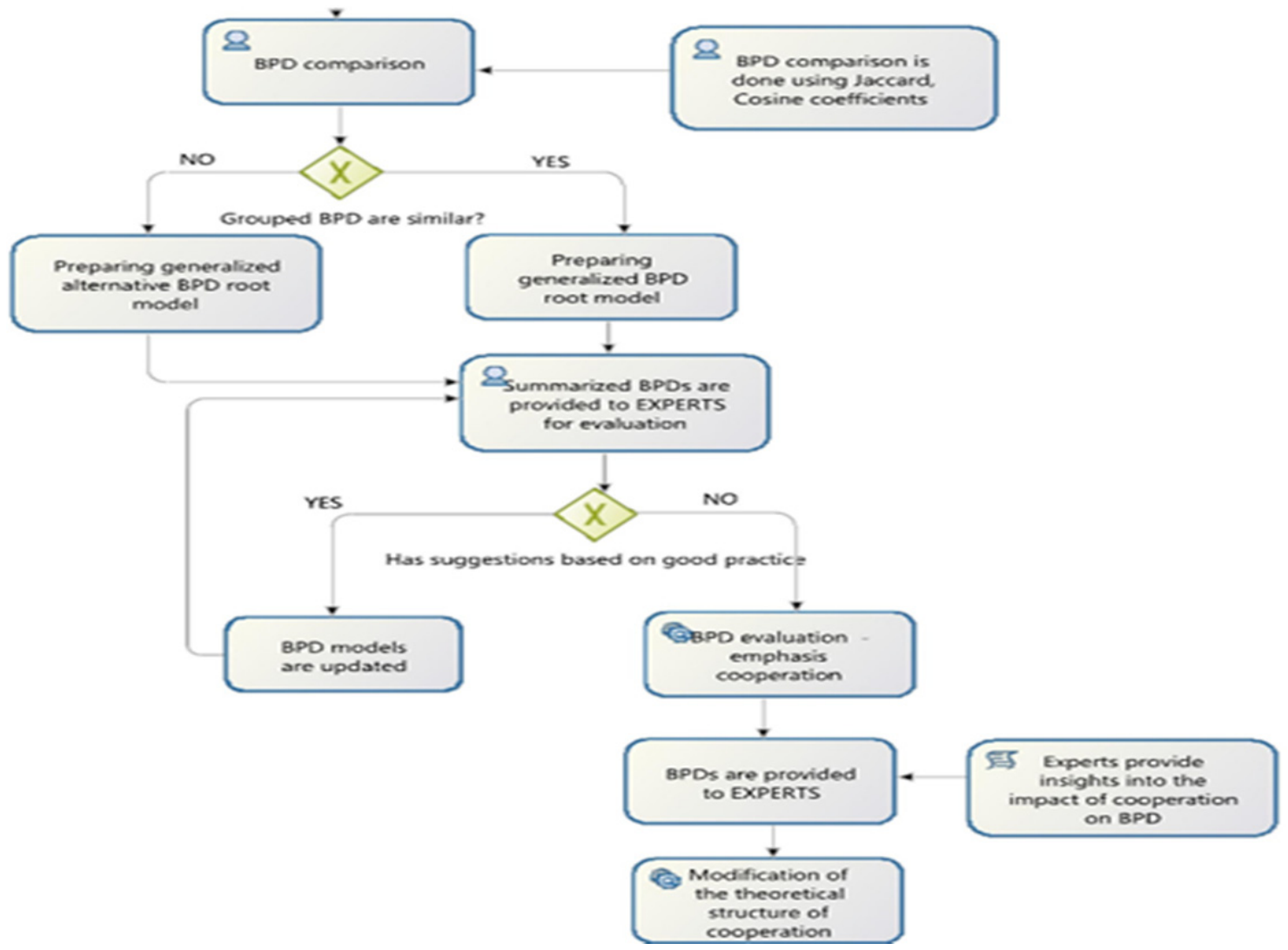

Fig. 3. The 3rd, 4th and 5th research stages: comparison, specification of business processes and evaluation of the impact of cooperation, Source: Compiled by the authors

The research has limitations: business processes in small metalworking manufacturing enterprises operating in cooperation with a medium or large enterprise of the same economic activity are investigated. In addition, the research provides generalized models of the core (main process areas) of business processes, distancing from various secondary, less significant elements of business processes. Of course, it will not be possible to summarize the results of the research for enterprises of other economic activities and other sizes.

\section{CONCLUSION}

Due to the very wide variety of businesses, it is not possible to unambiguously define business processes that are typical for all enterprises. Particularly peculiar business processes manifest in small and medium-sized enterprises. Therefore, when defining business 
processes, one has to specialize according to the size of enterprises, their economic activities, and their relations with other enterprises. Information technologies with special software are becoming more and more important in business process modelling and management.

In today's dynamic and global economy, cooperation among enterprises is gaining special importance. However, the forms and scope of cooperation are also very numerous and varied, which is why cooperation researchers have to specialize and impose a number of restrictions in this respect as well.

Information technologies and mathematical analysis methods are used to model business processes of enterprises, but the competencies and experience of experts in the field of business process management are crucial. Scientific concepts form a deductive basis for business process modelling, and the results of empirical research in this area inductively complement and concretize the relevant concepts.

\section{REFERENCES}

[1] George, G., Bock, A. J. (2011). The Business Model in Practice and its Implications for Entrepreneurship Research. Entrepreneurship Theory and Practice, vol. 35, no. 1, p. 83-111. [2] Baden-Fuller, Ch., Morgan, M. S. (2010). Business Models as Models. Long Range Planning, vol. 43, no. 2-3, p. 156-171.

[3] Zott, Ch., Amit, R. (2007). Business model designs and the performance of entrepreneurial firms. Organization Science, vol. 18, no. 2, p. 181-199.

[4] Zairi, M. (1997). Business process management: a boundary less approach to modern competitiveness. Business Process Management Journal, vol. 3, no. 1, p. 64-80.

[5] Rosemann, M, vom Brocke, J. (2015). The Six Core Elements of Business Process Management. Editors vom Brocke, J., Rosemann, M. Handbook on Process Management 1 Introduction, Methods and Information Systems. 2nd ed. Springer, Berlin/Heidelberg, p. 105122.

[6] Hammer, M. (2015). What is Business Process Management? Editors vom Brocke, J., Rosemann, M. Handbook on Process Management 1 - Introduction, Methods and Information Systems. 2nd ed. Springer, Berlin/Heidelberg, p. 3-16.

[7] Davenport, T. H. (1993). Need radical innovation and continuous improvement? Integrate process reengineering and TQM. Planning Review, vol. 21, no. 3, p. 6-12.

[8] Singh, P. K. (2012). Management of Business Processes Can Help an Organization Achieve Competitive Advantage. International Management Review, vol. 8, no. 2, p. 19-26. 
[9] Audretsch, D. B., Dohse, D. (2007). Location: a neglected determinant of firm growth. Review of World Economics, vol. 143, no. 1, p. 79-107.

[10] Brinkmann, J., Grichnik, D., Kapsa, D. (2010). Should entrepreneurs plan or just storm the castle? A meta-analysis on contextual factors impacting the business planning performance relationship in small firms. Journal of Business Venturing, vol. 25, no. 1, p. 2440.

[11] Tell, J. (2012). Managerial strategies in small, fast-growing manufacturing firms. Journal of Management Development, vol. 31, no. 7, p. 700-710.

[12] Mircea, M., Ghilic-Micu, B., Stoica, M., Sinioros, P. (2016). Inter-organizational Performance and Business Process Management in Collaborative Networks. Economic Computation and Economic Cybernetics Studies and Research, vol. 50, no. 2, p. 107-122.

[13] Graser, F., Jansson, K., Eschenbächer, J., Westphal, I., Negretto, U. (2005). Towards Performance Measurement in Virtual Organizations - Potentials, Needs and Research Challenges. Collaborative Networks and their Breeding Environments. Springer, New York.

[14] Zaklad, A., McKnight, R., Kosansky, A., Piermarini, J. (2004). The Social Side of the Supply Chain. Industrial Engineer, vol. 36, no. 2, p. 40-44.

[15] Owen, M., Raj, J. (2003). BPMN and Business Process Management. Introduction to the New Business Process Modeling Standard. Popkin Software. 